DOI https://doi.org/10.51647/kelm.2020.3.1.49

\title{
THE INFLUENCE OF POSITIVE LEGAL REGULATION ON THE STATE OF SATISFACTION OF HUMAN NEEDS AND INTERESTS
}

\author{
Anna Nakonechna \\ Assistant Professor at the Department of Theory and Philosophy of Law \\ Ivan Franko National University of Lviv (Lviv, Ukraine) \\ ORCID ID: 0000-0003-0622-9386
}

\begin{abstract}
In the article a question is analyzed in relation to forms of influence of positive legal regulation on the state of satisfaction of human needs and interests, namely:

a) a direct that relates to the legal needs itself. It consists that through these or other remedies such needs (interests) can be fully satisfied (one hundred percent)

b) indirect, which addresses all other needs and consists in promotion and satisfaction human needs and interests through a variety of legal means.

It has also been reviewed the basic directions of indirect influence of legal regulation on the state of satisfaction of human needs and interests:

1) descriptive (objectifying) (defining the content of human needs and interests);

2) orientation (indicating the person what tools and in what order it should use to satisfy a particular need and interest);

3) comparable (influencing the formation of a hierarchy of needs and interests according to their importance to the subject);

4) distribution (legal regulation serves as one of the means of distribution of basic social goods);

5) security (regulation of activities on safeguard and protection of values, and in case of their damage or destruction, the establishment of procedures for their rehabilitation).

It is emphasized that the level of realization of such directions of indirect influence by such regulation depends on a number of circumstances, among which decisive role is played by its social essence: it is the interest of the dominant part of society, whose will is usually expressed by such legal regulation (and sometimes by the interest of the whole society), the corresponding values determine how the state uses its right as an instrument (means of distribution and protection of the latter).

Key words: human need, interest, direct form of influence of positive legal regulation on the state of satisfaction of human needs and interests, descriptive (objectifying) direction of indirect influence of positive legal regulation on the state of satisfaction of human needs and interest, orientation direction of indirect influence of positive legal regulation on the state of satisfaction of human needs and interest, comparable direction of indirect influence of positive legal regulation on the state of satisfaction of human needs and interest, distribution direction of indirect influence of positive legal regulation on the state of satisfaction of human needs and interest, security direction of indirect influence of positive legal regulation on the state of satisfaction of human needs and interest.
\end{abstract}

\section{ВПЛИВ ПОЗИТИВНОГО ПРАВОВОГО РЕГУЛЮВАННЯ НА СТАН ЗАДОВОЛЕННЯ ЛЮДСЬКИХ ПОТРЕБ ТА ІНТЕРЕСІВ}

\author{
Анна Наконечна \\ асистент кафедри теорії та філософії права \\ Львівського начіонального університету імені Івана Франка (Львів, Україна)
}

ORCID ID: 0000-0003-0622-9386

Анотація. У статті проаналізовано питання щодо форм впливу позитивного правового регулювання на стан задоволення людських потреб та інтересів, а саме:

а) прямої, яка стосується власне правових потреб. Вона полягає у тому, що за допомогою тих чи інших юридичних засобів такі потреби (інтереси) можуть бути задоволені повністю (стовідсотково);

б) опосередкованої, яка стосується всіх інших потреб та полягає у сприянні задоволенню людських потреб та інтересів за допомогою різноманітних юридичних засобів.

Окрім цього розглянуто основні напрями опосередкованого впливу правового регулювання на стан задоволення людських потреб та інтересів:

1) позначальний (опредметнюючий) (окреслення змісту людських потреб та інтересів);

2) орієнтаційний (вказівка людині на те, які засоби та в якій послідовності їй варто використовувати для задоволення потреб та інтересів);

3) співвимірний (вплив на формування ієрархії потреб та інтересів відповідно до їх значущості для суб'єкта);

4) розподільчий (слугує одним із засобів розподілу основних соціальних благ);

5) охоронний (регламентація діяльності з охорони та захисту цінностей, а в разі їх пошкодження або знищення встановлення порядку їх відновлення).

Наголошено, що рівень реалізації таким регулюванням вказаних напрямів опосередкованого впливу залежить від низки обставин, серед яких вирішальну роль відіграє його соціальна сутність: саме зацікавленістю доміную- 
чої частини суспільства, чию волю зазвичай виражає таке правове регулювання (а іноді й зацікавленістю усього суспільства), у відповідних цінностях зумовлюється те, яким чином держава застосовує своє право як інструмент (засобів розподілу і захисту останніх).

Ключові слова: людська потреба, інтерес, пряма форма впливу позитивного правового регулювання на стан задоволення людських потреб та інтересів, позначальний (опредметнюючий) напрям опосередкованої форми впливу позитивного правового регулювання на стан задоволення людських потреб та інтересів, орієнтаційний напрям опосередкованої форми впливу позитивного правового регулювання на стан задоволення людських потреб та інтересів, співвимірний напрям опосередкованої форми впливу позитивного правового регулювання на стан задоволення людських потреб та інтересів, розподільчий напрям опосередкованої форми впливу позитивного правового регулювання на стан задоволення людських потреб та інтересів, охоронний напрям опосередкованої форми впливу позитивного правового регулювання на стан задоволення людських потреб та інтересів.

\title{
WPLYW POZYTYWNEJ REGULACJI PRAWNEJ NA STAN ZASPOKAJANIA LUDZKICH POTRZEB I ZAINTERESOWAŃ
}

\author{
Anna Nakonechna \\ asystent Katedry Teorii i Filozofii Prawa \\ Lwowskiego Uniwersytetu Narodowego im. Iwana Franki (Lwów, Ukraina) \\ ORCID ID: 0000-0003-0622-9386
}

\begin{abstract}
Adnotacja. W artykule przeanalizowano kwestie dotyczące form wpływu pozytywnej regulacji prawnej na stan zaspokajania ludzkich potrzeb i zainteresowań, a mianowicie:

a) bezpośredniej, odnoszącej się do faktycznych potrzeb prawnych. Polega ona na tym, że za pomocą pewnych środków prawnych takie potrzeby (interesy) mogą być w pełni zaspokojone (stuprocentowo);

b) pośredniej, która dotyczy wszystkich innych potrzeb i polega na przyczynianiu się do zaspokajania ludzkich potrzeb i zainteresowań za pomocą różnych środków prawnych.

Ponadto omówiono główne kierunki pośredniego wpływu regulacji prawnych na stan zaspokojenia ludzkich potrzeb i interesów:

1) oznaczalny (określający) (określanie treści ludzkich potrzeb i zainteresowań);

2) orientacyjny (wskazanie osobie, jakie środki i w jakiej kolejności powinny być wykorzystane do zaspokojenia potrzeb i zainteresowań);

3) współmierny (wpływ na kształtowanie hierarchii potrzeb i zainteresowań zgodnie z ich znaczeniem dla podmiotu);

4) dystrybucyjny (służy jako jeden ze środków dystrybucji podstawowych dóbr społecznych);

5) ochronny (regulacja działalności w zakresie obrony i ochrony wartości, a w przypadku ich uszkodzenia lub zniszczenia ustalanie trybu ich przywracania).

Należy zauważyć, że poziom realizacji takich regulacji tych kierunków pośredniego wpływu zależy od szeregu okoliczności, wśród których decydującą rolę odgrywa jego istota społeczna: to interes dominującej części społeczeństwa, którego wolę zwykle wyraża taka regulacja prawna (a czasem interes całego społeczeństwa), w odpowiednich wartościach zależy od tego, w jaki sposób państwo stosuje swoje prawo jako narzędzie dystrybucji funduszy i ochrony tych ostatnich).

Słowa kluczowe: potrzeba człowieka, zainteresowanie, prosta forma oddziaływania pozytywnej regulacji prawnej na stan zaspokojenia ludzkich potrzeb i zainteresowań, oznaczalny (określający) kierunek pośredniczej formy pozytywnego wpływu regulacji prawnych na stan zaspokojenia ludzkich potrzeb i zainteresowań, orientacyjny kierunek pośredniczej formy pozytywnego wpływu regulacji prawnych na stan zaspokojenia ludzkich potrzeb i zainteresowań, współmierny kierunek pośredniczej formy pozytywnego wpływu regulacji prawnych na stan zaspokojenia ludzkich potrzeb i zainteresowań, dystrybucyjny kierunek pośredniczej formy pozytywnego wpływu regulacji prawnych na stan zaspokojenia ludzkich potrzeb i zainteresowań, ochronny kierunek pośredniczej formy pozytywnego wpływu regulacji prawnych na stan zaspokojenia ludzkich potrzeb i zainteresowań.
\end{abstract}

Introduction. In general, it would be natural to assume that the relationship between needs and law is purely one-sided. Definitely, law (including probably all legal phenomena) is created to serve the man, to meet the needs of his existence and development. However, a more meticulous analysis shows that the law has the opposite effect on the formation of human needs and interests.

The purpose of the article is to consider the influence forms of positive legal regulation on the state of satisfaction of human needs and interests, namely: a) direct, which concerns peculiarly legal needs (consists in direct satisfaction); b) indirect, which affects all other needs and involves promoting and meeting human needs and interests through various legal means.

Statement of basic materials. The reverse influence of legal regulation on needs and interests is carried out in two forms:

a) direct, and

b) indirect.

The direct form of such influence concerns the actual legal needs (interests). It consists in the fact that with the help of certain legal means such needs (interests) can be met completely (hundred-per-cent).

Thus, the need of people for a visa-free regime led to the signing of the Visa Waiver Agreement between Ukraine and the EU [here is the official. text in English: https://eur-lex.europa.eu/legal-content/EN/TXT/ $\mathrm{PDF} /$ ?uri=OJ\%3AL\%3A2017\%3A133\%3AFULL\&from=EN], which took place in Strasbourg on May $17,2017$. Therefore, this Agreement turned out to be quite a sufficient mean to fully satisfy this legal need of the citizens of Ukraine. 
The indirect form of such influence affects all other needs (interests) and consists in promoting the satisfaction of human needs and interests through various legal means.

For example, the admission of an entrant as a student of a higher educational institution by the rector's order helps to satisfy his need for higher education. However, the specified enabling legislation in itself does not directly satisfy the specified needs of the entrant.

Indirect influence of legal regulation on the state of satisfaction of human needs and interests is carried out in such main areas as: signifying (objectifying), orientation, instrumental and commensurate, distributive and protective.

The first direction of influence can be characterized as the influence on the content of needs and interests, its change and formation.

Indeed, legal remedies have the ability not only to serve the satisfaction of a particular need that exists before and independently of them, but also to generate the need for that particular remedy. In psychology, it is called the need objectification direction. "Need in itself, as an internal condition of the subject activity, is only a negative state, a state of need, lack; it receives its positive characteristic only as a result of meeting with the object ("implementer") of its “objectification” (Леонтьев, 1971: 11).

The famous Soviet philosopher and psychologist, O. M. Leontiev notes: "We say, for example, that a person eats chocolate because he feels the need for chocolate; and such a need can really be felt. Everyone, however, understands that it is not the "chocolate" need inherent in some people creates their consumption of chocolate, but, conversely, the very fact of the existence of chocolate and the experience of its consumption creates a specific need to them" (Леонтьев, 1971: 11).

This is the nature of a person's need for justice, marriage, ensuring non-interference in his personal and family life, and so on. If, for example, to consider a person's need as a sufficient standard of living, it can be satisfied with sufficient food, clothing, housing in accordance with Art. $48 \mathrm{KU}$ as objects of its objectification.

This means exactly what P.M. Rabinovych once substantiated as an instrumental and defining value of law, which «consists in the fact that legal norms name, denote, point to those phenomena which, from the state's point of view, are intended to meet the needs of one or the other entities and therefore belong to the values. The right itself is a value here because it satisfies the information and orientational needs of the person» (Рабінович, 2006: 24).

The defining (objectifying) direction of the influence of legal regulation plays an extremely important role, as it depends on whether a particular need (interest) can be met.

The second direction of influence of legal regulation is influence on means of need satisfaction. The orientation direction indicates to the person what means and in what sequence it should be used in order to satisfy certain need (interest).

Thus, before filing a commercial claim, the legislator proposes to refer to pre-trial dispute resolution (Section 2 of the Commercial Code of Ukraine) as more efficient, faster and less expensive. A similar rule exists in family law: the spouses who have no dependent children can divorce in two ways: by submitting a joint application to the Registry Office or in a court. Once again, the legislator allegedly hints that it is better to apply to the Registry Office, and to go to court when there is no mutual consent of the spouses (Article 105 of the FCU) (Ciмейний кодекс України, 2002).

Part 2 of Art. 11 of International Covenant on Economic, Social and Cultural Rights notes such means as meeting the need for freedom from hunger, such as:

- improvement of production methods;

- storage and distribution of food by extensive use of technical scientific knowledge, dissemination of knowledge on the principles of nutrition and improvement or reform of agricultural systems so as to achieve the most efficient deployment and use of natural resources;

- ensuring an equitable distribution of world food stocks according to needs and taking into account the problems of countries both importing and exporting.

The orientation direction ensures the effectiveness of meeting the need, because a person will not use chaotic means to meet it, but will develop a fixed sequence of actions based on the rules of law.

This form of influence of legal regulation on the state of satisfaction of human needs and interests becomes possible due to the fact that P.M. Rabinovych defined as an instrumental and commensurate value of law. "It is known that the significance of actions, objects, phenomena is not the same for each subject and that it also changes in social time and social space ... Thus, the value objectivity itself is objectively hierarchical and such hierarchy is obligatory for the appropriate mode of existence of the social subject. Of course, the subjective hierarchy of values must correspond to it. One of the ways to form the latter in a socially heterogeneous society is law" (Рабінович, 2006: 28)

As noted in the literature, the instrumental and commensurate direction of the impact of legal regulation is usually realized through the following technical and legal means:

- location of the description of legally distributed values according to their comparative significance in the regulatory legal acts of different legal force. Consequently, the subjective hierarchy of the regulatory legal acts reflects with some degree of certainty the objective hierarchy of values. Through the prism of the legal and regulatory hierarchy, one can trace the value hierarchy, which is protected by law, ultimately determined by the needs and interests of the dominant class (Неновски, 1982: 95, 97). Thus, the Basic Law (Constitution), which has the highest legal force in the system of all regulatory legal acts, usually fixes the largest and the most important, from the point of view of the dominant class, vital values; 
- assignment of values in the norms of different industry affiliation. Thus, the protection of certain social relations by criminal law means that they are recognized as an extrinsic value that is important for the existence, normal life of society (Демидов, 1975: 43);

- distribution, placement of a detailed description of values in different sections of one law;

- inclusion in the regulatory legal acts of instructions on the priority or preference in the choice of certain values in the relevant situation, in particular in case of their conflict, when the law-making body is forced to give preference to certain interests and values or even protect some interests and values to the detriment of others. At the heart of such a conflict may be contradictions, mismatches of needs, namely: a) individual; b) individual, group and general social; c) national and international; d) long-term and short-term; e) reasonable and unreasonable, etc. These contradictions are resolved by establishing criteria for prioritizing needs and increasing the adequacy of their awareness. The criteria approved by the state are enshrined in law;

- legislative consolidation of the prohibition, unconditional inadmissibility of encroachment on certain values, which in such system of public relations are recognized as absolute. Other benefits, which, from the point of view of the legislator, in some situations, in particular in the protection of absolute values, may be caused by a certain damage, are, compared with the first, relative values;

- establishment in the legislation of various types and sizes of incentives according to the level of value of subject's actions;

- legislative ranking of types and sizes of sanctions for offenses depending on the degree of value of the encroachment object. The more valuable an object that is damaged or destroyed as a result of an illegal act, the more severe sanction is provided for encroaching on it. Thus, the hierarchy of sanctions (if it is correct and justified), being directly proportional to the degree of usefulness of law enforcement values, is a kind of reflection of their own hierarchy (Рабінович, 2006: 27-28).

As an example of ranking of administrative penalties depending on value of encroachment objects we will consider Art. 47, 52 and 172-10 of the Code of Ukraine about Administrative Offenses. It is indicated in Art. 47 that the unauthorized use of subsoil, the conclusion of agreements that directly or implicitly violate the right of ownership of subsoil, entail the imposition of a fine on citizens in the amount of ten to thirty non-taxable minimum incomes for citizens and from thirty to one hundred non-taxable minimum incomes for officials. Art. 52 points out that the deterioration of agricultural and other lands, their contamination with chemical and radioactive substances, oil and petroleum products, untreated wastewater, industrial and other wastes, as well as failure to take measures to control weeds, entail the imposition of fines on citizens in the amount of twenty to eighty non-taxable minimum incomes for citizens and officials and from fifty to one hundred non-taxable minimum incomes for subjects of entrepreneurial activity. Art. 172-10 stipulates that refusal to comply with the lawful requirements of the commander (chief) entails the imposition of a fine in the amount of seventy to one hundred forty five non-taxable minimum incomes or arrest with detention on guard duty for up to seven days. As we can see, the order of execution in the military formations of Ukraine of orders, which provides the necessary in the conditions of military service relations of subordination and military honor, which is the object of the offense in Art. 172-10, is of greater value than public relations in the field of subsoil protection and in the field of rational land use and land protection, which is the object of offenses in Art. 47 and 52 respectively.

In addition to ranking, the official grading of legal liability measures according to the degree of their severity characterizes the comparative significance of those values that the state deprives the offender depending on the severity of the offense (Рабінович, 2006: 28). Such a gradation of measures of legal responsibility is demonstrated, in particular, in Art. 24 of the Code of Ukraine about Administrative Offenses, which specifies the following types of administrative penalties: 1) warnings; 2) fine; 2-1) penalty points; 3) paid seizure of an object that has become an instrument of commission or a direct object of an administrative offense; 4) confiscation: of an object that has become an instrument of commission or a direct object of an administrative offense; money received as a result of committing an administrative offense; 5) deprivation of a special right granted to a given citizen (right to drive vehicles, right to hunt); deprivation of the right to hold certain positions or engage in certain activities; 5-1) public works; 6) corrective work; 6-1) socially useful works; 7) administrative arrest; 8) arrest with detention on guard duty.

In summary, the instrumental and commensurate direction of the influence of legal regulation ensures the correct alignment of priorities in values to meet the needs (interests), as well as the obligation to be responsible for violations of the rules of law.

The fourth form of legal regulation influence on needs (interests) is the distributive direction. In a socially heterogeneous society, law acts primarily as a means of distribution and provision of basic social benefits, so it is seemed to be their formal source. It becomes, so to speak, an «accomplice» in meeting the most important needs of the subjects and a co-organizer of their life necessities.

The level of distributive value of the right is determined by two factors: firstly, the content and scope of the needs of the subject; secondly, the specific types and amounts of those benefits that are rightfully made available to the subject to meet its needs. Consequently, to establish the value of the right in the mentioned aspect, as well as to determine its place in the general system of social means of meeting the needs and interests of the subject is possible only pursuant to what part of the needs (interests) are satisfied by the benefits provided by such right. Operational indicators that allow measuring the level of such value of the right and obtaining its quantitative characteristics can be, in particular, the following indicators:

- the specific density of those needs (interests) that are met only through the law, as part of all needs and interests of the subject; 
- comparative significance for the life of the subject of those needs (interests) that cannot be satisfied outside the law, and those that are met outside it;

- degree of satisfaction of needs (interests) mediated by law (Рабінович, 2005: 11).

Obviously, such indicators are in themselves non-legal, general social, although their selection takes place against the background of law, as if it were with its participation. The quantitative value of such indicators may change primarily due to general social changes - due to: 1) the emergence of new needs (i.e. the need for new goods); 2) expansion or narrowing of the sphere of manifestation of already existing needs (i.e. increase or decrease of the circle of subjects who have such needs); 3) quantitative change of the need itself (its increase or decrease); 4) actualization of the corresponding need, i.e. strengthening of its urgency in vital activity of subjects and reflection of this circumstance in hierarchy of conscious installations of subjects.

Any fluctuations in these indicators, which may be caused by abovementioned reasons, will reflect changes in the value of the law in its instrumental and distributive aspect. But at the same time it is obvious that just as the increase of such value of the right cannot be set as "the merit" directly to such aspect, and its decrease should not be set as "the fault". If objective legal law does not directly produce material and spiritual benefits, then it is not "responsible" for their type and scope. Therefore, in this aspect, the value of the right is its derivative, dependent, secondary characteristic. Law in this sense is a value to the same extent as the politics, economics, morality and the spiritual life of society as a whole have the quality of values. The law, even for all its importance, versatility, does not add anything fundamentally new to the general "nomenclature" of social values, "although it significantly strengthens, enriches them" (Алексеев, 1978: 127). It only seems to be colored in the color of the value that it distributes (Алексеев, 1978: 12).

The specified direction ensures the distribution of benefits in accordance with the needs and interests of a human, thus satisfying them. However, it should be remembered that due to the above general social changes, the law is not able to meet all needs (interests) due to lack of relevant benefits.

An example of the distributive direction of the influence of legal regulation on meeting the material needs of the relevant subjects can be Art. 70 and Art. 71 of the Family Code of Ukraine, which enshrine the general procedure for the distribution of spouses' property as material benefits in the event of divorcement, which would satisfy the need of each of them to ensure adequate living conditions. Art. 70 stipulates that in the case of division of property that is the object of the right of joint ownership of the spouses, the shares of the property of the wife and husband are equal, unless otherwise provided by agreement between them or by the marriage contract. Art. 71 specifies certain nuances of such a division. Absolutely, property is divided between them in kind. If they do not agree on the order of division of property, the dispute may be resolved by a court. In this case, the court takes into account the interests of the wife, husband, children and other circumstances that are significant (Part 1). Indivisible things are awarded to one of the spouses, unless otherwise specified by agreement between them (Part 2). Things for professional activities are awarded to the spouse who used them in their professional activities. The value of these things is to be taken into account when awarding other property to the second spouse (Part 3 of Article 71).

The fifth form of influence of legal regulation on the needs and interests is the protection direction, which consists in the fact that the law regulates actions for protection, protection of values, and in case of their damage, destruction establishes the order of their restoration. Therefore, any violation of the rule of law "due to the value that it is protected, acts on society directly and very significantly" (Алексеев, 1978: 16).

Usually everyone has such a social need as respect for their honor and dignity and their protection. As it is commonly known, positive law provides legal instruments that help meet this need, namely by going to court with a claim for protection of honor and dignity (Part 3 of Article 297 of the Civil Code of Ukraine).

The above direction is key, because without the security and protection of values, the law will not be able to meet the needs and interests.

Conclusion. To conclude, given all the above mentioned forms of feedback effect, positive legal regulation is just a very important instrumental value in meeting the needs (interests) of an individual or a certain (mostly dominant) part of society, or all participants in public life, or society as a whole. in general.

The level of implementation of such regulation of such areas of indirect influence depends on a number of circumstances. Among them, its social essence plays a decisive role: it is the interest in respective values of the dominant part of society, whose will is usually expressed by such legal regulation (and sometimes the interest of society as a whole), determines how the state uses its law as a tool (means of distribution and protection of the latter). The role of legal regulation in solving general social problems is also quite important, although it is also carried out by it under the control of the interests of the dominant part of society. It is performed to the extent and in the form that they adjust.

Summing up, we should note that the quality of the implementation of positive legal regulation of the above areas of feedback effect largely depends on, firstly, the completeness and accuracy of knowledge of the needs (interests) of the person, the dominant part of society and other subjects, and, finally, society as a whole, and secondly, on the role of law in meeting the needs and interests to which the state attaches legal significance.

\section{Bibliography:}

1. Леонтьев А.Н. Потребности, мотивы и эмоции. Москва : Изд-во Моск. ун-та, 1971. 40 с.

2. Рабінович П.М. Социалистическое право как ценность. Одесса : Юрид. Лит, 2006. 167 с.

3. Сімейний кодекс України : Закон України від 10.01.2002 p. № 2947-III. URL: https://zakon.rada.gov.ua/laws/ show/2947-14 
4. Неновски Н. Право и ценности. София, 1982. 416 с.

5. Демидов Ю.А. Социальная ценность и оценка в уголовном праве. Москва, 1975. 185 с.

6. Рабінович П.М. Інструментальна цінність об’єктивного юридичного права. Вісник Академї правових наук України. 2005. № 3(42). С. 8-13.

7. Алексеев С.С. Право и наша жизнь. Москва, 1978. 224 с.

References:

1. Leont'ev A.N. (1971) Potrebnosty, motyvy y emotsyy [Needs, motives and emotions]. M.: Yzd-vo Mosk. Un-ta, 40 s. [in Russian]

2. Rabinovych P.M. (2006) Sotsyalystycheskoe pravo kak tsennost' [Socialist law as a value]. Odessa: Yuryd. Lyt., 167 s. [in Ukrainian]

3. Simejnyj kodeks Ukrainy [Family Code of Ukraine] : Zakon Ukrainy vid 10 sichnia 2010 r. № 2947-III. URL: https://zakon.rada.gov.ua/laws/show/2947-14

4. Nenovsky N. (1982) Pravo y tsennosty [Law and values]. Sofyia. 416 s. [in Russian]

5. Demydov Yu.A. (1975) Sotsyal'naia tsennost' y otsenka v uholovnom prave [Social value and evaluation in criminal law]. M., 185 s. [in Russian]

6. Rabinovych P.M. (2005) Instrumental'na tsinnist' ob'iektyvnoho jurydychnoho prava [Instrumental value of objective law]. Visnyk Akademii pravovykh nauk Ukrainy. № 3(42). S. 8-13. [in Ukrainian]

7. Alekseev S.S. (1978) Pravo y nasha zhyzn' [Law and our life]. Moskva. 224 s. [in Russian]

DOI https://doi.org/10.51647/kelm.2020.3.1.50

\title{
МІСЬКЕ САМОВРЯДУВАННЯ УКРАЇНСЬКИХ МІСТ У СЕРЕДНЬОВІЧЧІ
}

\author{
Віталій Нестор \\ кандидат юридичних наук \\ ORCID ID: 0000-0002-8194-1392
}

\begin{abstract}
Анотація. Метою статті є дослідити міське самоврядування за часів середньовіччя та сформулювати висновки і пропозиції, які стануть у нагоді під час аналізу сучасного стану самоуправління у містах України. Завданнями, спрямованими на досягнення цієї мети, є проаналізувати позиції сучасних українських вчених щодо магдебурзького права.

Дослідження побудоване на основі превалювання історичного методу. Також застосовуються такі методи, притаманні юридичній науці: аналіз, синтез, індукція, дедукція. У процесі проведення дослідження автор спирався на герменевтичний та аксіологічний підходи до вибраної проблематики. Варто наголосити на важливих для дослідження сучасного стану самоуправління міст в Україні положеннях: а) у кожному місці самоврядування було унікальним, унікальність зумовлювалась особливостями, потребами міста; b) у кожному місті самоврядування було самодостатнім із точки зору наявності представницьких органів, їхніх виконавчих органів (посадової особи з виконавчими функціями), а також судових органів.

Нарешті, варто підкреслити - далеко не усі міста на території сучасної України мали права організовувати самоврядування відповідно до грамот, виданих у межах магдебурзького чи хелмінського права. Такі грамоти отримували лише найбільш значні за обсягом населення чи за своїми політичними, економічними тощо функціями міста. Невеликі міста, які не мали відповідних грамот, застосовували менш складну систему міського самоврядування. Як правило, вона охоплювала колегіальний представницький орган (на зразок ради), його керівника (на зразок бургомістра, війта) та виконавчий орган. Здебільшого відсутність магдебурзької грамоти означала відсутність у місті міського суду - лави.

Нині в Україні доцільно рекомендувати впровадити підхід, відповідно до якого самоврядування міст має бути не уніфікованим, а адаптованим щодо викликів, які стоять перед територіальними громадами.

Ключові слова: місцеве самоврядування, міста, середньовічні міста, магдебурзьке право, магдебурзька грамота, історія міського самоврядування.
\end{abstract}

\section{URBAN GOVERNMENT OF UKRAINIAN CITIES IN THE MIDDLE AGES}

\author{
Vitalii Nestor \\ Candidate of Law Sciences \\ ORCID ID: 0000-0002-8194-1392
}

\begin{abstract}
The aim of the article is to study city government during the Middle Ages and to formulate conclusions and proposals that will be useful in analyzing the current state of the city government in Ukraine. The tasks aimed at achieving this goal are to analyze the positions of modern Ukrainian scholars on Magdeburg law.

The study is based on the prevalence of the historical method. Methods inherent in legal science, such as analysis, synthesis, induction, deduction, are also used. In conducting the study, the author relied on hermeneutic and axiological
\end{abstract}

